\title{
Opportunities of Higher School in Students' Leadership Development
}

\author{
Marfuga Absatova \\ Nesibeli Kalkayeva \\ Marat Ushatov \\ Gulmera Saudabaeva \\ Diana Tektibayeva
}

RSE on PEA Kazakh National Pedagogical University named after Abai, Correspondence: Dostyk ave. 13 Almaty, Kazakhstan Email: absatovamar@mail.ru, tektibyevadiana@mail.ru

\section{Doi:10.5901/mjss.2015.v6n3s1p187}

\section{Abstract}

The article describes the main approaches to the problem of leadership. Scientific analysis of psychological and educational literature showed that the interest to the leadership and an attempt to understand this complex and important social phenomenon date back to antiquity. Theory of leadership aims to identify a universal structure of an effective leader personality, defining its inherent traits or characteristics. A number of researchers attempted to define a set of characteristics peculiar to the leader. At the same time, consistent with the level of manufacture development at the stage under consideration, they put at the first place alternately the physical strength, or the intellect.

Keywords: leadership, leadership qualities, leader, characteristics, ability, managing skills.

\section{Introduction}

Positive processes taking place in Kazakhstan related primarily to the stabilization of the socio-political conditions, socioeconomic status of the people, modernization of education, put forward new requirements to the training of young professionals.

Our state defines the social order for the education of person who is professionally competent, morally developed, competitive, having leadership qualities, capable to cooperate, ready to make own decisions in any situations, responsible for the destiny of his/her country.

Higher educational institutions in every possible way take into account all the requirements of modern society: nowadays in all the universities there taking place a transition to learning, based on the competency-based approach which allows guaranteeing personal efficiency and mobility of graduates in a changing conditions of labor market and the realization in Kazakhstan of the provisions of the Bologna Declaration.

However, as it is evident from the analysis of existing practices, in the educational process of higher educational institution there is a lack of activities aiming to form students' leadership qualities.

Methods: analysis of the main concepts of the research on the basis of philosophical, psychological, pedagogical, cultural, sociological literature, governmental documents, and analytical materials of the Ministry of Education and Science of the Republic of Kazakhstan analytical study, generalization and interpretation of scientific data.

\section{Main Part}

\subsection{The trends of Leadership investigation}

Analysis of pedagogists' and psychologists' papers on the problems of the development of students' leadership indicated that this problem had not got enough attention in terms of higher educational institution.

Thus, we can say that at the present time in the theory of education and in the practice of universities there are the necessary preconditions for a deeper theoretical conceptualization and systemic presentation of the problem of the 
development of leadership qualities in student's personality.

It should be noted that the analysis of scientific psychological and pedagogical literature has shown that the interest to the leadership and attempts to comprehend this complex and important social phenomenon date back to antiquity. So, ancient historians like Herodotus, Plutarch and others have paid the main attention to political leaders, seeing the history makers in heroes, monarchs and generals.

The phenomenon of leadership excited the minds of many researchers for centuries. At the beginning of the $X X$ century the investigation of management began. Management and leadership have become the object of research. In 3050 s there have been a number of large-scaled studies held in a systematic way (Solovykh, 2011).

Since 70s, the interest to the study of leadership began to grow even more, as a result there appeared the works written by J. Mc. Gregor Burns, R. Tucker, B. Kellermann, J. Piaget (Solovykh, 2011).

Leadership - is a multidimensional social phenomenon. The phenomenon of leadership appears in any more or less organized groups aiming a common goal. It is difficult to give a general definition to leadership. It is due to the fact that leadership appears anytime and everywhere, where a group of people have to deal with any matters affecting the interests of all or the majority of members (Ross et al., 2005).

It is possible to distinguish the following basic approaches to its investigation:

Leadership - it is a kind of power that is implemented by one or more individuals. The most characteristic feature of this power is its top-down trend.

Leadership is the administrative status, social position, connected with the decision-making, and that is an executive position.

Leadership - it is a kind of influence on other people, which meet the following conditions:

the influence must be permanent rather than episodic;

the influence of the leader should be extended to the whole group (organization);

a leader must have a clear priority of his influence;

the influence of a leader, especially of organized one, should be based not on a direct use of force, but on the authority, or at least the recognition of the legitimacy of management;

Leadership - an informal influence. It differs from the guidelines, which provides a fairly rigid and formalized system of relationship management - submission.

Leader - a symbol of community and group behavior pattern. He "comes forward" from the bottom, mostly spontaneously and is accepted by followers (Bezuglyi, 2007).

\subsection{The notion of Leadership}

As it is well known, we are used to see the word "leader" or "leadership" in different collocations: a political leader, the leader of the nation, a religious leader. We are talking about people who were able to influence on the course of history by their own unwavering faith in the justice of their deed, the ability to inspire and lead the masses of people.

"Leadership is required in all components of the system," - said E. Deming (Niv, 1998). And, above all, the most important is the leading role of top management, without which the structural transformations are difficult, or even are not impossible. Obviously, the leadership - is a key element of the innovation process and of a support of a quality culture in the organization. Leadership - is the key that opens the door to business success.

R. Edgemen (Edgeman, 1998) says that the success of the new organization, aimed on the quality depends on leadership that creates inner conditions for this. Undoubtedly, the ultimate success of the corporation will depend on the ability of its employees to work together creatively in order to achieve a common goal. But here again, it is impossible to do without the leadership, which nourishes and supports the necessary skills and the attitude that is required. Today leadership - it is no more than the definition of the height at which it is necessary to jump (Horner, 1997).

Leadership - is not only an essential component, but it is also an indispensable one. Its absence will entail a significant loss of competitiveness (Foster, 1987).

Leadership is everywhere, where there is a power and organization. The word "leader" means "leading" or "guiding". This meaning still persisting today it has long been familiar to all peoples.

Significant contribution to the study of political leadership has made Machiavelli (Machiavelli, 1999). In his treatment a political leader - is a sovereign, rallying and representing the whole society and using any means in order to maintain public order and preserve own supremacy. Machiavelli developed practical advices for rulers, involving skillful combination of cunning and strength appreciated by Cromwell, Napoleon and many other prominent politicians (Machiavelli, 1999).

Conception of leadership that influenced on the subsequent political ideology and practice was developed by 
Friedrich Nietzsche (1844-1900). He tried to justify the need for the formation of higher biological type - human-leader, the superman. "The goal of humanity - wrote Nietzsche - lies in its supreme representatives ... Humanity must work tirelessly to bring forth great humans - this, and nothing else, is its mission" (Shalaginova, 2007).

The direct impact on the modern concepts of leadership had made Gabriel Tarde (1843-1904), one of the founders of the theory of socialization. G. Tarde tried to prove that the basic law of social life is an imitation of the followers to the leader. Most of the population has no ability to independent social creativity. The only source of society progress - are the discoveries made by initiative and ingenious personalities (Shalaginova, 2007).

However, these researches were not enough to get a unique representation of the personality traits of the leader. In 1948, Ralph Stogdill collated more than 50 studies about the character traits of leaders in order to develop a single model, but eventually came to the conclusion that such a model does not exist.

\section{Results}

Many researchers attempted to define a set of characteristics that turns a person into a leader. At the same time, depending on the level of production development on the stage under consideration, they put at the first place either the physical strength, or an intellect (Lewin et al., 1939).

So, the studies have identified ten key characteristics of the managers that are proper to a modern leader:

The ability to form a management team;

A strategic vision of the business development;

The ability to manage strategic changes in business development;

The ability to make decisions under uncertainty conditions;

The factor of self-discipline and organization;

The ability to delegate authority and control the process of gaining the desired results;

The ability to establish constructive relationships within the collective;

The ability to establish and maintain constructive relationships with external parties;

Detailed knowledge of business processes and the production specificities of the enterprise or industry;

The ability to negotiate and persuade in the rightness of own position.

M. Chemers in the four-volume handbook on social psychology recently released in Europe, speaking about the variety of interpretations of leadership notion, mentions as the most widespread the view on leadership as a process of influence by which man bespeaks the others people's support, and directs their efforts to achieve collective goals. Scientist pays attention to several important, in his opinion, elements of this definition. Firstly, in terms of the presence of a collective goal. This means that leadership is a collective process. Secondly, the momentum of influence is emphasized in the leadership. This means that leadership is not a process of enforcement, but includes obtaining and using the help from other people.

Thirdly, leadership is considered as a social phenomenon. According to M. Chemers, it means that the sources and goals of leadership are enclosed in the nature of group activity and its complete understanding is possible only in the case of understanding of the broader social processes and of their psychological components (Chemers, 2001).

According to R. Hogan and his colleagues "leadership - is a belief, not domination. People, who may require other people's submission to their orders because they have the power over them, are not leaders. Leadership occurs only when others are willing to temporarily accept the group's goals as their own" (Hogan et al., 1994).

Analysis of the scientific literature reveals that the concept of leadership is inseparable from the concept of personal authority, it is the socio-psychological process in the group, which is based on the influence of the personal authority of the leader on the behavior of group members (Pugachev, 2011; Leadership, 2006).

The role of the leader is to lead people, to ensure the existence of such relations between people that contribute to the solution of concrete problems in the frames of common goal.

Leadership and management are largely identical concepts, in Western psychology, they have the same value. Management provides conversion of opportunities into reality. Effective management should be aimed at the decision, development, integration and enrichment of the organization's potential and abilities of its employees.

An effective manager, as well as a leader, has an impact on his/her subordinates or colleagues, which helps to motivate them to move towards particular purposes.

It should be noted that the "Leadership - is one of the mechanisms for the integration of group activity, when an individual or a part of a social group plays the role of a leader, i.e. unites, guides the entire group, which expects, receives and supports these actions. Partially overlapped by the concepts of "direction", "management", leadership at the same time characterizes a specific form of relationships in a group or organization" (Vechorko, 2007). 
"Leader - is a member of a group, who can significantly influence in important situations on the behavior of other participants" (Dushkov et al., 2005).

Definitions given in the encyclopedias of recent years, almost coincide with each other and are as follows: "The leader - is a member of the group which recognizes his/her right to make decisions relevant to the situation, that is, the most authoritative personality, really playing a central role in the organization of joint activities and in regulation of the relationship within a group" (Kondratiev et al., 2006).

"The manager - is the person who is officially entrusted the management of a collective and the organization of its activities" (Antsupov and Shipilov, 2009).

Thus, summarizing the above mentioned it can be stated that the common element of all definitions of leadership in Western social psychology comes to the recognition of the action motivation maintenance as an important factor presented by the leader to all group members during the achievement of group tasks. In this sense, the leader is a person who comes close to the realization and implementation of the norms and values of the group.

Disclosure of the contents of the leadership concept has enabled us to identify some of the ways of forming these qualities at a person. One of these ways, to our mind, is the presentation of the authorial course "Leadership", which can provide conceptualization and engagement of students into the development of professional values and leadership qualities. The main objective of this course - is the formation of skills of leadership, organizational culture, motivation of students' creativity, training of project activity in the conditions of students' self-administration.

Objectives of the "Leadership" course:

- $\quad$ to expand the nature and content of the "Leader"concept;

- to study the direction of leadership development through the investigation of works of foreign and Kazakh scientists;

- to develop students' leadership skills;

Here, we present the themes of lectures and seminars, as well as their basic content in the Table 1.

Table 1. Calendar-thematic plan of "Leadership" study course

\begin{tabular}{|c|c|c|c|}
\hline$\#$ & Themes. Basic content & Lectures & Seminars \\
\hline 1 & $\begin{array}{l}\text { Aim and objectives of the "Leadership" course } \\
\text { 1. The nature and content of the "Leader"concept } \\
\text { 2. Aim and objectives of the "Leadership" course }\end{array}$ & 1 & \\
\hline 2 & $\begin{array}{l}\text { The formation of the Leadership theories } \\
\text { 1. The formation of the Leadership theories in "western" science } \\
\text { 2. The development of leadership theories in Russia 3. The development of pedagogical ideas in } \\
\text { Kazakhstani science }\end{array}$ & 1 & 1 \\
\hline 3 & $\begin{array}{l}\text { The correlation of the Leader and the Manager notions } \\
\text { 1. the correlation of the Leadership and the Leader notions } \\
\text { 2. Phenomena of Leadership and Manager }\end{array}$ & 1 & \\
\hline 4 & $\begin{array}{l}\text { Styles and functions of the Leader in the group } \\
\text { 1. Functions of Leaders in a group } \\
\text { 2. The styles of Leadership }\end{array}$ & 1 & 1 \\
\hline 5 & $\begin{array}{l}\text { The qualities of Leaders } \\
\text { 1. Ideas of researchers, scientists and Kazakh enlighteners about leadership qualities } \\
\text { 2. The essence of the qualities peculiar to leaders. }\end{array}$ & 1 & 1 \\
\hline 6 & $\begin{array}{l}\text { Structural-content model of the development of personal leadership qualities } \\
\text { 1. The opportunities of the development of personal leadership qualities } \\
\text { 2. Structural-content model of the development of personal leadership qualities }\end{array}$ & 1 & 1 \\
\hline 7 & $\begin{array}{l}\text { Peculiarities of the development of students' leadership qualities } \\
\text { 1. Psychological peculiarities of the development of students' leadership qualities } \\
\text { 2. Pedagogical peculiarities of the development of students' leadership qualities }\end{array}$ & 1 & 1 \\
\hline 8 & $\begin{array}{l}\text { Methodology of the development of personal leadership qualities } \\
\text { 1. The role of the interactive methods in the } \\
\text { 2. The essence of the extracurricular activities in the development of personal leadership qualities }\end{array}$ & 1 & 2 \\
\hline & Total & 8 & 7 \\
\hline
\end{tabular}

Thus, it should be noted that the concept of leadership is widespread in sociology, political science, psychology, and in other sciences of mankind and society. This phenomenon is an object of extensive theoretical and empirical researches. 
The study of leadership has a direct pragmatic reasoning. First of all, it serves for the development of methods of effective management, as well as the selection of leaders. In Western countries, there were created a variety of psychometric and sociometric tests and techniques that are successfully used in practice.

At the same time, we believe that the introduction of a special authorial course developed by us will allow revealing the phenomenon more widely and will help the formation of the students' leadership qualities.

\section{Discussions}

It is clear that the leadership as a phenomenon is based on certain objective needs of highly organized systems. These include, above all, the need for self-organization, the regulation of the behavior of individual elements of the system in order to ensure its vital and functional capacity. This regulation is done via vertical (direction-submission) and horizontal (single-leveled communication) distribution of functions and roles, and, above all, through the provision of administrative functions and realizing its structures, which requires a hierarchical, pyramidal organization for its effective work. As the peak of this management pyramid stands none other than the leader.

Accuracy of the leading positions selection depends on the type of community, as a part of the system, on its relationship with the surrounding reality. In systems with low group integration, and a high degree of autonomy of various levels of the organization and the freedom of the individual elements, leader's functions are underdeveloped. As far as the needs of the system and people themselves in the highly organized collective action and perception of these needs in the form of collective goals increase, the need for a leader and a specification of his/her functions is also increased.

Thus, taking into account the above-mentioned, it is possible to give such definitions, leadership - is a type of administrative cooperation, which is based on more efficient for a concrete situation combination of different power sources and directed on the encouragement of people to achieve common goals. Leader - is a person who has a general recognition of the group and who is able to conduct people.

In our study, under the leadership qualities we understand a set of character traits that contribute to effective communication, responsible decision-making, and mastering the profession that is connected with the management related activities.

\section{Summary}

A considerable amount of researches are devoted to a problem of leadership. Various approaches to this problem can be divided into the following main groups: the theories of personal qualities of a leader; behavioral theories of leadership; theories of leadership based on the situational approach; procedural theories of leadership.

Analysis of the literature showed that the word "leader" has many meanings as: 1) Leading, Manager; 2) A ship heading group, a caravan of ships; 3) An athlete or sports team coming first in the competition; 4) A biker riding ahead a cyclist (Race to the Top). A term definition of Leadership is following - Management relationship between the leader and the followers, based on an effective for the situation combination of different power sources and aimed at encouraging people to achieve common goals.

Modern researches have shown that effective leaders are really different from other people on several characteristics, including: motivation to leadership - the leader wants to lead people and influence others; cognitive abilities - leaders can process and interpret large amounts of information; adaptability - leaders can adapt to the needs of their fundamentals followers and to the changing demands of the situation.

\section{References}

Antsupov, A.Ya., A.I. Shipilov, 2009. Dictionary of a conflictologist.

Bezuglyi, D.L., 2007. Leadership and team management. State University - Higher School of Economics. Moscow, pp: 100.

Chemers M. Leadership Effectiveness: An Integrative Review // M.Hogg \& S.Tindale (eds.). Blackwell Handbook of Social Psychology: Group Processes. University of Oxford (UK), 2001. Vol. 3.

Dushkov, B.A., A.V. Korolev, B.A. Smirnov, 2005. Encyclopedic dictionary: psychology of labor, management, engineering psychology and ergonomics.

Ed. Kondratiev, M., L.A. Karpenko, A.V. Petrovsky, 2006. Psychological lexicon. Encyclopedic dictionary in six volumes. PER SE, pp: 176.

Edgeman Rick, L., 1998. Principle - centered leadership and core value development. The TQM Magazine, Vol.10, 3, pp:190-193.

Foster, R., 1987. Update production: the attackers win: Translated from English. Moscow: Progress, pp: 272.

Hogan R., Curphy G. \& Hogan L. What we Know about Leadership. Effectiveness and Personality // American Psychologist. 1994. Vol. 
49.

Horner, M., 1997. Leadership theory: past, present and future // Team professional management, Vol.3, 4, pp: 270-287.

Leadership. Translated from English, 2006. Alpina Business Books, pp: 258.

Lewin, K., Lippitt, R., \& White, R. K., 1939. Patterns of aggressive behavior in experimental created "social climates." Journal of Science Psychology, 10, pp: 271-299.

Machiavelli, N., 1999. The Prince: Oeuvre. pp: 656.

Niv, G.R., 1998. The space of Dr. Deming. Vol. 1: Translated from English. - Togliatti: Municipal public fund "Development through quality", pp: 332.

Pugachev, V.P., 2011. Identification, development and protection of leadership. Elitarium. www.elitarium.ru /2011/09/16/vyjavlenie_ razvitie_zashhita_liderstva.html

Ross, J., S. Maurice, G. Wilcox, E. Neyzel, 2005. Leader and team. A practical guide of effective team leader. Balance Business Books, pp: 296.

Shalaginova, L.V., 2007. Leadership psychology. St. Petersburg, pp: 458.

Solovykh, N.N., 2011. Theoretical-methodological basics of the nature of leadership phenomenon. III International Correspondence Scientific and Practical Conference "Innovation processes and corporate governance", Minsk.

Vechorko, G.F. 2007. Basics of psychology and pedagogy: answers on exam questions. Minsk: TetraSistems, pp: 160. 